\title{
On the Construction of the Teaching System of Innovation and Entrepreneurship Education in Universities
}

\author{
Haoyue $\operatorname{Ren}^{1 *}$ \\ ${ }^{1}$ Tianjin University of Technology and Education, Hexi District, Dagu South Road, Tianjin,China
${ }^{*}$ Corresponding author. Email: 86094713@qq.com
}

\begin{abstract}
With the continuous development of innovation and entrepreneurship education in Chinese universities, innovation and entrepreneurship education courses are becoming more and more important. Constructing a scientific curriculum and teaching system for innovation and entrepreneurship education is conducive to popularizing entrepreneurial ideas, improving college students' innovation and entrepreneurship capabilities, and enhancing the effectiveness of universities innovation and entrepreneurship education. Based on the analysis of the current situation and existing problems of university innovation and entrepreneurship education courses, this article puts forward the concept of a "modular" teaching system for university innovation and entrepreneurship, and discusses the safeguards for the operation of the system.
\end{abstract}

Keywords: university, innovation and entrepreneurship education, teaching system.

\section{INTRODUCTION}

Since the release of the "Implementation Opinions on Deepening the Reform of Innovation and Entrepreneurship Education in Colleges and Universities" issued by the General Office of the State Council, universities have further deepened school teaching reforms in order to implement national policies, fully mobilize the enthusiasm and initiative of teachers and students to participate in innovation and entrepreneurship activities, and promote college students' innovation Entrepreneurship education has helped college students cultivate innovative spirit, establish entrepreneurial awareness, improve the structure of innovative knowledge, master entrepreneurial skills, lead entrepreneurship with innovation, and drive employment with entrepreneurship, forming a more systematic innovation and entrepreneurship education system.At present, although most universities offer corresponding innovation and entrepreneurship courses, it is not known whether the curriculum system and evaluation standards can effectively reflect the effects of innovation and entrepreneurship education. Innovation and entrepreneurship education courses are an important way to achieve the goals of innovation and entrepreneurship education, and it is a major issue to vigorously strengthen the curriculum system construction of university innovation and entrepreneurship education.

\section{THE CURRENT STATUS OF INNOVATION AND ENTREPRENEURSHIP EDUCATION COURSES İN UNIVERSITIES}

\subsection{Current status of innovation and entrepreneurship education courses in foreign universities}

The research of foreign entrepreneurship emerged in the 1960s, mainly focusing on the micro-fields, and most of it was carried out around entrepreneurs and their entrepreneurial spirit and resource integration. The United States has the most outstanding research on undergraduate entrepreneurship, which mainly focuses on the individual entrepreneurship of undergraduates, followed by the study of individual groups. The research methods mainly adopt case studies, and the research perspectives are mostly reflected in the quality of undergraduates and the external environment. In the United States, the teaching methods of entrepreneurship 
education in universities include discussion, business plan writing, lectures by visiting professors, case studies, entrepreneurial speeches, research plans and so on.

\subsection{Current status of innovation and entrepreneurship education courses in Chinese universities}

The curriculum construction of innovation and entrepreneurship education in Chinese universities is relatively lagging. In 1997, Tsinghua University first proposed the concept of entrepreneurship education in universities. The holding of Tsinghua University "Entrepreneurship Planning Competition" officially opened the curtain of entrepreneurship education in Chinese universities.In 2002, Tsinghua University and Renmin University of China were established as pilot programs for entrepreneurship education in Chinese universities. In August 2012, the Ministry of Education issued the "Basic Requirements for Entrepreneurship Education in General Undergraduate Schools (Trial)" (referred to as "Basic Requirements"). It is the first time to regulate entrepreneurship education in Chinese colleges and universities, requiring undergraduate colleges and universities to offer "foundation of entrepreneurship" compulsory courses, which must be included in the teaching plan, no less than 32 hours, no less than 2 credits, and requirements for entrepreneurship education teaching content Based on the teaching of entrepreneurial knowledge, the training of entrepreneurial ability is the key, and the cultivation of entrepreneurial spirit is the core. It should be oriented to the whole, combined with professional, and strengthen the educational principles of practice.The release of the "Basic Requirements" provides a basis for universities to carry out innovation and entrepreneurship education [1]. Renmin University of China focuses on improving the overall ability of students and reflects innovation and entrepreneurship education in the form of a second classroom; Beihang University emphasizes how to tap students' innovative and entrepreneurial skills and complete its commercial operation by building a college student entrepreneurship park.

\section{PROBLEMS IN THE CONSTRUCTION OF UNIVERSITY INNOVATION AND ENTREPRENEURSHIP EDUCATION COURSES}

Curriculum is the carrier of teaching activities and the basic way to achieve educational goals. In innovation and entrepreneurship education, curriculum construction is also a core issue. However, universities still have not formed a systematic entrepreneurship curriculum, and there are many problems [2].

\subsection{Inaccurate understanding of innovation and entrepreneurship education}

Entrepreneurship education is to cultivate pioneering people. It is very important for cultivating personal initiative and adventurous spirit, entrepreneurial and independent working abilities, as well as technical, social, and management skills. Universities are required to take entrepreneurial skills and entrepreneurial spirit as the basic goals of higher education, and upgrade them to the same important status as academic research and vocational education. Although universities generally pay more attention to innovation and entrepreneurship education, the entrepreneurial guidance courses of most schools are difficult to implement the teaching goals of entrepreneurial concepts and cultivating entrepreneurial spirit.

\subsection{Incomplete construction of the innovation and entrepreneurship curriculum system}

Looking at the construction of innovation and entrepreneurship courses in China, in terms of quantity and variety, the overall number of innovation and entrepreneurship courses is relatively low, and the courses are mainly based on knowledge and skills. The courses are mainly for undergraduates, and the nature of the courses is mainly elective courses; In terms of training methods, it is mainly to popularize the basic knowledge of innovation and entrepreneurship for all students in the school. Some universities offer "entrepreneurship classes" focusing on cultivating a small number of students who are interested in entrepreneurship or meet the required conditions and offer corresponding entrepreneurship courses; innovation and entrepreneurship education courses include "creation "Learning", "KAB Entrepreneurship Fundamentals for College Students" courses and "SYB" courses. Some universities will involve entrepreneurial knowledge in career guidance courses, which mainly focus on teaching the definition of entrepreneurship, which lacks systematicness. On the whole, the curriculum of innovation and entrepreneurship education is relatively scattered, and there is no systematic innovation and entrepreneurship education curriculum, which needs to be further deepened and expanded.

\subsection{The curriculum of innovation and entrepreneurship education is not practical}

College students' innovation and entrepreneurship courses should be based on practice. The teaching content and teaching mode of the courses should be different from theoretical courses, and a lot of practical activities are needed as support. However, most universities in China lack practical resources for entrepreneurship courses. The practice of 
entrepreneurship courses is carried out through lectures and exchanges by some entrepreneurs and related experts, which is poor in practice [3]. Although some universities provide students with entrepreneurial incubation bases and entrepreneurial practice bases, some college students do not have practical opportunities due to space and funding.

\subsection{The level of teachers in innovation and entrepreneurship education courses is not high}

First of all, there is no uniform entry standard for innovation and entrepreneurship education teachers in universities. They only arrange personnel according to needs, rather than setting up positions according to the requirements of the profession; Secondly, in management, whether the profession of innovation and entrepreneurship education teachers is included in the teacher series or the administrative series, The statement is not clear. Schools have different operating standards, and the development of teachers is restricted, which affects the development of teaching work. Then, most schools have fewer full-time teachers engaged in innovation and entrepreneurship education, and more part-time teachers. Undertaking many tasks such as ideological and political education of college students, student management, etc., affecting teachers' learning enthusiasm and professional development; Finally, there are very few teachers with professional background in innovation and entrepreneurship in universities, lacking practical experience in entrepreneurship, and can only teach theoretical knowledge.

\section{CONSTRUCTION AND IMPLEMENTATION OF THE "MODULAR" TEACHING SYSTEM OF INNOVATION AND ENTREPRENEURSHIP EDUCATION COURSES}

\subsection{Establish a leading group for innovation and entrepreneurship}

The leading group for undergraduate innovation and entrepreneurship is responsible for coordinating students' innovation and entrepreneurship. The group leader and deputy team leader are the main leaders of the university. The establishment of an innovation and entrepreneurship education curriculum implementation guarantee system consisting of four levels: school, related departments, departments, and classes, And clarify the specific responsibilities, work objectives, work measures and other content of each level. Relying on the characteristics of the disciplines and majors of each department, various innovation and entrepreneurship organizations should be established to provide students with education on entrepreneurship foundation, entrepreneurship quality, entrepreneurship ability, entrepreneurship practice, etc, and cultivate high-quality technology from professional teachers and financial support. Economic projects and high-quality innovative and entrepreneurial talents provide software and hardware guarantees.

\subsection{Strengthen the construction of innovative and entrepreneurial teams}

Universities should clarify the status and role of teachers in innovation and entrepreneurship education, clarify the development prospects of this team, stabilize this team, and make some teachers willing to engage in this profession full-time. Select and hire a group of experienced and enthusiastic education instructors from enterprises, banks and other industries to serve as parttime entrepreneurship instructors, realize the combination of professional and concurrent in entrepreneurship guidance, complement each other, and gradually establish a "combination of professional and reasonable structure, and outstanding ability "Innovation and entrepreneurship education teachers [4].

\subsection{Update teaching content to the curriculum system}

Universities can jointly develop module courses with enterprises, continuously update the content of teaching, and write the latest achievements, lessons and management concepts of enterprises into textbooks, so that students can obtain the most cutting-edge and practical knowledge of innovation and entrepreneurship. Encourage students to participate in teacher scientific research projects and innovation and entrepreneurship training projects to stimulate students' interest in science and technology and spirit of exploration, improve students' science and technology innovation skills and entrepreneurial abilities, and enable more college students to obtain national patents. In particular, strengthen guidance and carefully organize students to participate "Entrepreneurship Challenge Cup" extracurricular science and technology and academic works, entrepreneurial plans, model aircraft, robotics, mathematical modeling and other competitions, and guide qualified students to establish technology-based enterprises with certain technical content. Schools should actively use existing resources to establish an entrepreneurship training base for college students on campus to provide a practical platform for college students to establish business entities.

\subsection{Strengthen the construction of innovation and entrepreneurship disciplines and courses}

The main disciplines of innovation and entrepreneurship education include creativity, psychology, economics, and human resource 
management. At present, training is an effective way to improve the professional level of innovation and entrepreneurship teams. However, from the perspective of long-term development, it is necessary to establish an innovation and entrepreneurship guidance discipline, set up innovation and entrepreneurship majors in university classrooms, and carry out innovation and entrepreneurship professional talent training, in order to truly realize the professionalization of innovation and entrepreneurship guidance. However, this is indeed a long process, requiring a long period of time to accumulate and the joint efforts of schools and teachers.

\section{CONCLUSION}

Curriculum system is the carrier of education to achieve training goals and the key to guarantee and improve the quality of education in the teaching process. Innovation and entrepreneurship education has become an important part of university education and leads the overall education and teaching reform. To build an innovation and entrepreneurship curriculum system, it is necessary to deeply understand the connotation and essence of innovation and entrepreneurship education, and it is also necessary to deeply realize that practical activities are the key to innovation and entrepreneurship education.

\section{AUTHORS' CONTRIBUTIONS}

Based on the analysis of the current situation and existing problems of university innovation and entrepreneurship education courses, this article puts forward the concept of a "modular" teaching system for university innovation and entrepreneurship, and discusses the safeguards for the operation of the system.

\section{ACKNOWLEDGMENTS}

First of all, this thesis has been carefully guided by the teacher in the topic selection and research process. The teacher asked about the research process many times to help me develop my thesis ideas. Therefore, I am very grateful to the teacher. Finally, thank my parents and friends for their support and understanding for many years.

\section{REFERENCES}

[1] Jinying. Wang and Weiji. Liu, Reflection and reconstruction of college students' entrepreneurship education from the perspective of ecological civilization, vol. 5, Research in Ideological and Political Education, 2013, pp. 112-115.

[2] Jiahua. Li and Xudong. Lu, Integrate innovation and entrepreneurship education into the talent training system of colleges and universities. vol. 6, Higher Education, 2010, pp. 38-41.
[3] Zhongxin. LI, Discussion on the Current Situation and Countermeasures of the Construction of Undergraduate Entrepreneurship Courses. vol. 6, Journal of Jilin Radio and Television University, 2013, pp. 23-24.

[4] Wenbo. Peng and Xinming.Yin and Guanfeng. Li, Exploration and practice of innovation and entrepreneurship education curriculum system construction. vol. 4, Innovation and Entrepreneurship Education, 2010, pp. 56-58. 